\title{
Effect of Plant Density on the Yield of Hydroponically Grown Heat-Tolerant Tomato under Summer Temperature Conditions
}

\author{
Alex Williams Ayarna1, Satoru Tsukagoshi ${ }^{1 *}$, George Oduro Nkansah², Kazuya Maeda ${ }^{3}$ \\ ${ }^{1}$ Center for Environment, Health and Field Sciences, Chiba University, Chiba, Japan \\ ${ }^{2}$ Forest and Horticultural Crops Research Centre, School of Agriculture, College of Basic and Applied Sciences, University of \\ Ghana, Accra, Ghana \\ ${ }^{3}$ National Agriculture and Food Research Organization, Tsukuba, Japan \\ Email: ayarna2011@gmail.com, ^tsukag@faculty.chiba-u.jp, gonkansah2013@gmail.com, maedakazuya0515@gmail.com
}

How to cite this paper: Ayarna, A.W., Tsukagoshi, S., Nkansah, G.O. and Maeda, K. (2021) Effect of Plant Density on the Yield of Hydroponically Grown HeatTolerant Tomato under Summer Temperature Conditions. American Journal of Plant Sciences, 12, 901-913.

https://doi.org/10.4236/ajps.2021.126060

Received: May 3, 2021

Accepted: June 8, 2021

Published: June 11, 2021

Copyright $\odot 2021$ by author(s) and Scientific Research Publishing Inc. This work is licensed under the Creative Commons Attribution-NonCommercial International License (CC BY-NC 4.0). http://creativecommons.org/licenses/by-nc/4.0/ (C) (i) (5) Open Access

\begin{abstract}
Producing enough tomato to meet market demand sustainably has not been feasible in the tropics like Ghana. Attempts to improve production using greenhouse facilities have not addressed the challenge because of hightemperature conditions in the greenhouse, which are difficult to manage. Heat stress, arising from high temperatures, hinder the performance of tomato in terms of fruit set and yield. Moreover, the impending climate change is expected to impose more unfavorable environmental conditions on crop production. An experiment was conducted in (greenhouse at Chiba University, Japan) summer period, which has similar high-temperature conditions like Ghana. This work sought to increase the yield of a heat-tolerant tomato using a state-of-the-art hydroponic system through high-density planting. The outcome of this work was intended for adoption and practice in Ghana. A Heat-tolerant tomato "Nkansah HT" along with Lebombo and Jaguar cultivars, were grown at high and low plant densities (4.1 and 2.7 plants $\mathrm{m}^{-2}$ respectively). Each plant was grown in a low substrate volume culture $(0.5 \mathrm{~L}$ plant $^{-1}$ ) in a recirculating nutrient film technique (NFT) hydroponic system. Parameters measured were plant growth and dry matter assimilation at 12 weeks after transplanting, and the generative components. Results showed that a high plant density increased plant height but reduced chlorophyll content by $9.6 \%$. Under temperature stress conditions, the three cultivars recorded more than $95 \%$ fruit set, but plant density did not affect the fruit set and the incidence of blossom end rot (BER). The incidence of BER reduced the marketable yield of the Jaguar cultivar by $51 \%$ but, this physiological disorder was not recorded in the HT and the Lebombo cultivars. A high-density planting increased the yield per unit area increased by $38.9 \%$. However, it is uneconom-
\end{abstract}


ical to cultivate the Jaguar cultivar under a heat stress condition due to its high susceptibility to blossom end rot. To improve the yield of tomatoes under tropical heat stress with a threatening climate change condition, the HT is a better cultivar suited for high-density planting. This study shows that highdensity cultivation of the HT cultivar in NFT hydroponic system has the potential to increase Ghana's current tomato yield by 4.8 times.

\section{Keywords}

Heat-Tolerant, Heat Stress, Hydroponics, Plant Density, Tomato, Yield

\section{Introduction}

Increasing the yield of tomatoes to meet market demand sustainably is a major challenge facing Ghana. This challenge emanates from the fact that tomato production in Ghana has been based on inadequate cultivation systems, the lack of high-yielding cultivars, and others. Additionally, tomato crop cultivation under extremely high temperatures, especially in the tropics, is besetting with a low or poor fruit set. The poor fruit set results in a reduced yield of tomato, especially in the dry seasons.

Furthermore, climate change issues like high temperatures are advancing with threats to tomato crop cultivation in the tropics [1] [2] and other regions [3]. It has been reported by Johkan et al. [4] that, aside from the adverse physiological impacts, the high temperature could also favour the proliferation of insect pests and diseases. These negatively affect tomato production. In general, it has been predicted by Gunawardena and De Silva [5] that the growth and yield of tomato plants will be adversely affected by high temperatures. The yield of tomatoes is expected to reduce by $5 \%-10 \%$ [6] [7] [8]. Too high temperatures reduce fruit set [9] and induce blossom end rot [10]. Also, it has been predicted that damage to crop plants by phytopathogen and insect pests will be devastating [1] with the advent of climate change.

In advancing climate change, it has been reported that heat-tolerant tomato cultivars are better to cultivate [4] [11]. Such cultivars have been reported to set fruit, even under high night temperatures above $21^{\circ} \mathrm{C}$ [12] maintain net photosynthetic rate, under heat stress [13].

For proper utilization of the cultivation area, optimum plant density is required [14]. Heuvelink et al. [15] showed that crop yield could be affected by excessively low or too high plant density. They indicated that plant density could induce competition and shade effect. According to Menberu et al. [16], a decrease in plant density increases the unmarketable yield of tomatoes. It was reported that a high plant density increased marketable fruit yield [17]. Conversely, Geremew et al. [18] reported that plant density does not significantly affect the total fruit yield of tomatoes. In a nutshell, Ara et al. [14] stressed that an increase in plant density leads to an increasing fruit yield of tomatoes. It was further emphasized 
by Akintoye et al. [19] that yield per unit area increased with an increase in plant density. Fruit number increases with an increase in plant density.

In 2014, greenhouse technology was introduced for tomato and other vegetable crop cultivation in Ghana. However, it had not been without difficulty managing temperatures inside the greenhouse. Fink et al. [20] stressed that proper management of the climate in the less advanced greenhouses is very challenging. Also, appropriate tomato cultivars have not been cultivated in tune with the changing climate. Consequently, the performance of tomatoes has been adversely affected because of the low fruit set and blossom end rot. In tropical regions with high temperatures, De la Pena and Hughes [5], Bita and Gerats [21], and Solh and van Ginkel [22] suggested using heat-tolerant tomato cultivars for high fruit set.

This study sought to increase the yield of a heat-tolerant tomato in a high-density planting under high summer temperature conditions (like Ghana's). This work was to be performed in a state-of-the-art hydroponics system, which is not available in Ghana. This system is characterized using a low substrate volume (reducing production cost) with a recirculating technique (conserving water and nutrients). With the conservation of resources, a reduced production cost could render the cultivation system affordable and adoptable. The outcome of this work was intended for adoption and practice in Ghana.

\section{Materials and Methods}

\subsection{Treatments}

The study was conducted in the summer period, between May 23 and August 20, 2018, in the greenhouse of Chiba University, Japan.

Three cultivars of tomato were evaluated in a plant density of 2.7 and 4.1 plants per unit area. A heat-tolerant tomato "Nkansah HT" (obtained from the University of Ghana, Forest, and Horticultural Crops Research Center, KadeGhana) was evaluated along with two tropical cultivars. The tropical cultivars were Jaguar and Lebombo (obtained from Technisem, Savanna Seed Company limited, Longue-Jumelles, France, and Proceed Company, Benoni-South Africa, respectively. Information regarding heat tolerance for the Jaguar and the Lebombo cultivars has not been provided in the literature.

The experiment was laid out in a $3 \times 2$ factorial in the randomized complete block design with three replications. Each treatment consisted of twenty plants, and data were analyzed by the analysis of variance. Data collected were analyzed using the GenStat (Rothamsted Research, Harpenden, UK) while Tukey's honest significant difference $\left(\mathrm{LSD}_{0.05}\right)$ was used to separate the means at $\mathrm{p}<0.05$.

\subsection{Cultivation Conditions}

The seeds were sown in coconut shell fiber (Cocopeat, Top Co. Ltd, Japan) on May 23, 2019. The germinated seedlings were transferred to an artificial lighting chamber equipped with a day/night temperature of $23^{\circ} \mathrm{C} / 18^{\circ} \mathrm{C}, \mathrm{CO}_{2}$ supply at $1000 \mu \mathrm{moL} \mathrm{moL}{ }^{-1}$ for a $16 \mathrm{~h}$ photoperiod. These conditions were adopted in order to raise stout and healthy seedlings. The nutrient solution was supplied ac- 
cording to half-strength of the Enshi Shoho recipe [23] described below. A specially designed $0.5 \mathrm{~L}$ capacity planting pot, with a bottom water-permeable aperture, was filled with coconut shell fibre as the substrate. Transplanting was carried out on the third week after germination into a recirculating nutrient film. Uptake of nutrients and water was by capillary action. The half-strength Enshi Shoho recipe adopted was $\left(0.7 \mathrm{mM} \mathrm{NH}_{4}-\mathrm{N}, 8 \mathrm{mM} \mathrm{NO}_{3}-\mathrm{N}, 1.3 \mathrm{mM} \mathrm{PO}_{4}-\mathrm{P}, 4 \mathrm{mM}\right.$ $\mathrm{K}, 2 \mathrm{mM} \mathrm{Ca}, 1 \mathrm{mM} \mathrm{Mg}, 2 \mathrm{mM} \mathrm{SO}_{4}-\mathrm{S}, 3 \mathrm{ppm} \mathrm{Fe}, 0.5 \mathrm{ppm} \mathrm{B}, 0.5 \mathrm{ppm} \mathrm{Mn}, 0.02$ ppm $\mathrm{Cu}, 0.05 \mathrm{ppm} \mathrm{Zn}, 0.01 \mathrm{ppm} \mathrm{Mo}$ ) and supplied through sub-irrigated hydroponic technique. Daily, the electrical conductivity of the nutrient solution was maintained at $0.12 \mathrm{~S} \cdot \mathrm{m}^{-1}$ and the $\mathrm{pH} 5.5-6.5$ throughout the cropping cycle. The heat-tolerant cultivar had stopped flowering at the fourth week after transplanting. In order to synchronize the growth of the three cultivars, plants of the Lebombo and the Jaguar were topped at the third leaf above the second truss.

\subsection{Data Collection}

\subsubsection{Plant Growth}

Plant height, leaf number, and chlorophyll content were measured on the twelfth week after transplanting (WAT). The plant height was determined using a ruler from the base to the uppermost part of the plant. The chlorophyll content was measured at the leaves below the youngest trusses, using a chlorophyll meter, SPAD-502 (Konica-Minolta Inc., Tokyo, Japan). Three plants were randomly sampled, where the leaves were detached and scanned with a camera. The scanned leaves were analyzed for the leaf area using (https://www.agr.nagoya-u.ac.jp/ shinkan/LIA32/, accessed on August 21, 2019). The leaf area ratio (LAR) was calculated as the leaf area divided by the total plant dry weight. The leaf weight ratio (LWR) was determined as the total leaf dry weight divided by the total plant dry weight.

\subsubsection{Dry Matter Production and Partitioning}

At the twelfth week after transplanting, the three randomly sampled plants were separated into leaves, stem, root, and fruit. The different components were ovendried at $72^{\circ} \mathrm{C}$ until a constant dry weight was obtained on the sixth day. Summing up all the components, the mean total plant dry weight was determined. The dry shoot weight was determined as the sum of the leaf and the dry stem weight.

\subsubsection{Generative Components}

Days to fifty percent anthesis was determined as the number of days within which fifty percent of the plants flowered. Fruit set percent was determined as the total number of fruits formed, divided by the total number of flowers present per plant. Blossom end rot (BER) percent was calculated as the total number of fruits affected by the incidence of BER divided by the total number of fruits produced per plant. The yield per unit area was calculated as the fresh fruit weight per plant multiplied by 2.7 or 4.1. Fruits were selected from the various treatments and scanned for the total soluble solids (TSS) using the K-BA100R spectrophotometer (Kubota, Yao, Japan). 


\subsection{Greenhouse Ambient Temperature and Humidity during the Cropping Cycle}

The daily maximum and the minimum readings for temperature and humidity were recorded using the Smart Sensor AR 867 thermo-hygrometer, Arco Science and Technology, China. The readings are shown in Figure 1 and Figure 2.

\section{Results}

\subsection{Plant Growth}

The plants cultivated at a high density grew taller than those at low density by the twelfth week after transplanting (Table 1). The Nkansah heat-tolerant (HT) recorded the lowest plant height compared to Lebombo and Jaguar. Significantly, the Lebombo plants cultivated at a high density were taller than the plants in the other treatments.

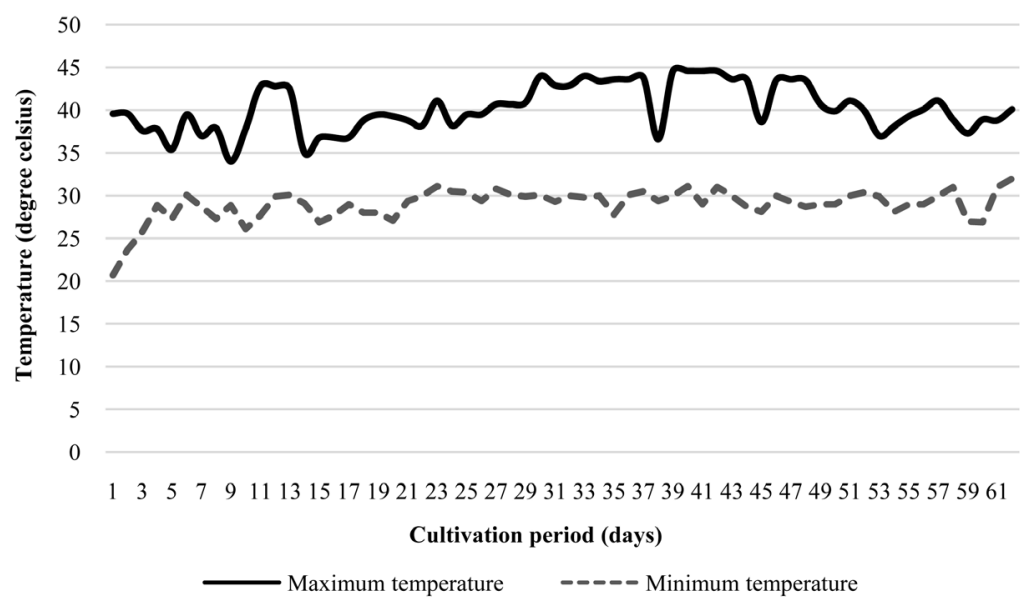

Figure 1. Greenhouse ambient temperature.

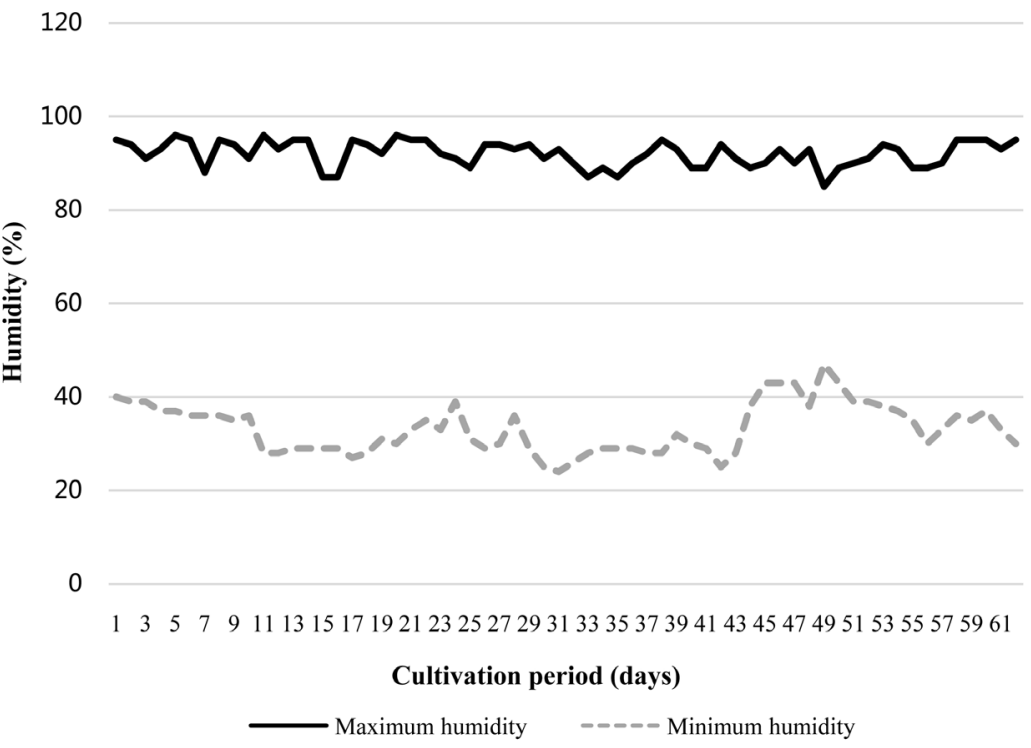

Figure 2. Greenhouse ambient humidity. 
Table 1. Growth of tomato as influenced by plant density at 12 weeks after transplanting.

\begin{tabular}{|c|c|c|c|c|c|c|}
\hline $\begin{array}{l}\text { Cultivar } \\
\text { (C) }\end{array}$ & $\begin{array}{l}\text { Height } \\
(\mathrm{cm})\end{array}$ & $\begin{array}{c}\text { Leaf } \\
\text { number }\end{array}$ & $\begin{array}{l}\text { SPAD } \\
\text { value }\end{array}$ & $\begin{array}{l}\text { Leaf Area } \\
\left(\mathrm{cm}^{2}\right)\end{array}$ & $\begin{array}{c}\text { LAR } \\
\left(\mathrm{cm}^{2} / \mathrm{g}\right)\end{array}$ & $\begin{array}{c}\text { LWR } \\
\left(\mathrm{mg} \cdot \mathrm{g}^{-1}\right)\end{array}$ \\
\hline $\mathrm{HT}$ & $78.2 \mathrm{c}$ & $36.3 a$ & $46.8 \mathrm{~b}$ & $1270 \mathrm{~b}$ & $6.8 \mathrm{c}$ & $161.2 \mathrm{~b}$ \\
\hline Lebombo & $121.1 \mathrm{a}$ & $12.3 \mathrm{~b}$ & $48.5 \mathrm{~b}$ & $1430 \mathrm{a}$ & $12.9 \mathrm{a}$ & $226.2 \mathrm{a}$ \\
\hline Jaguar & $92.6 \mathrm{~b}$ & $10.4 \mathrm{c}$ & $55.6 \mathrm{a}$ & $1131 c$ & $10.6 \mathrm{~b}$ & $158.2 b$ \\
\hline $\operatorname{HSD}_{(0.05)}$ & 8.2 & 1.3 & 2.9 & 129.4 & 1.3 & 30 \\
\hline \multicolumn{7}{|c|}{ Plant density (PD) } \\
\hline High & $102.4 \mathrm{a}$ & $19.7 \mathrm{a}$ & $48 \mathrm{~b}$ & $1248 \mathrm{a}$ & $10.5 \mathrm{a}$ & $180.5 \mathrm{a}$ \\
\hline Low & $92.2 \mathrm{~b}$ & $19.6 \mathrm{a}$ & $52.6 \mathrm{a}$ & $1307 a$ & $9.8 \mathrm{a}$ & $183.2 \mathrm{a}$ \\
\hline $\mathrm{HSD}_{(0.05)}$ & 6.6 & 1.1 & 2.3 & 105.6 & 1.1 & 20 \\
\hline \multicolumn{7}{|c|}{$\mathrm{C} \times \mathrm{PD}$} \\
\hline $\mathrm{HT} \times$ high & $82.8 \mathrm{de}$ & $36.3 \mathrm{a}$ & $45.8 \mathrm{~d}$ & $1258 b \mathrm{c}$ & $6.8 \mathrm{~d}$ & $167.5 b$ \\
\hline $\mathrm{HT} \times$ low & $73.6 \mathrm{e}$ & $36.3 \mathrm{a}$ & $47.7 \mathrm{~cd}$ & $1283 b c$ & $6.9 \mathrm{~d}$ & $154.9 \mathrm{~b}$ \\
\hline Lebombo $\times$ high & $128.3 \mathrm{a}$ & $12.5 \mathrm{~b}$ & $45.8 \mathrm{~d}$ & $1514 a$ & $13.6 \mathrm{a}$ & $220.2 a$ \\
\hline Lebombo $\times$ low & $113.8 \mathrm{~b}$ & $12.2 \mathrm{~b}$ & $51.2 \mathrm{bc}$ & $1346 \mathrm{ab}$ & $12.4 \mathrm{ab}$ & $232.3 a$ \\
\hline Jaguar $\times$ high & $96 c$ & $10.1 \mathrm{c}$ & $52.4 \mathrm{~b}$ & $1148 \mathrm{c}$ & $11.0 \mathrm{bc}$ & $153.8 \mathrm{~b}$ \\
\hline Jaguar $\times$ low & $89.2 \mathrm{~cd}$ & $10.6 \mathrm{bc}$ & $58.8 \mathrm{a}$ & $1114 \mathrm{c}$ & $10.3 \mathrm{c}$ & $162.6 \mathrm{~b}$ \\
\hline $\operatorname{HSD}_{(0.05)}$ & 11.5 & 1.8 & 4.1 & 182.9 & 1.8 & 40 \\
\hline
\end{tabular}

$\mathrm{HT}=$ Nkansah heat-tolerant tomato; LAR = leaf area ratio: LWR = leaf weight ratio Figures with the same letter in the same column are not significantly different according to Tukey's HSD at $\mathrm{p}<0.05$.

Plant density did not significantly influence the number of leaves produced (Table 1). Leaf number produced in the HT was 24 to 26 higher than Lebombo and Jaguar. The HT produced a higher leaf number than the other cultivars in all the treatments.

High density planting showed a reduced chlorophyll content than the low density planting (Table 1). The Jaguar plants showed a higher chlorophyll content than the plants in the other cultivars. Chlorophyll content was not affected by plant density in the HT cultivar. However, the other cultivars showed reduced chlorophyll content in a high plant density.

Leaf area was not affected by plant density (Table 1). The Lebombo produced a higher leaf area than the other cultivars. Plant density did not affect the photosynthetic area for the individual cultivars.

Plant density did not alter the leaf area ratio significantly (Table 1). Compared to the other cultivars, the HT plants recorded the lowest leaf area ratio. The leaf area ratio recorded in the individual cultivars did not differ with plant density.

Leaf weight ratio was not influenced by plant density (Table 1 ). The leaf weight ratio observed in the HT was similar to the Jaguar but was significantly lower than the Lebombo. The leaf weight ratio recorded in the different cultivars 
did not vary with plant density.

\subsection{Dry Matter Production and Partitioning}

The HT plants produced the highest plant dry weight compared to the other cultivars (Table 2). Plant dry matter production did not vary with plant density. The individual cultivar showed no variation in plant dry matter production with plant density. Dry matter allocated to shoot, root, and fruit did not differ with plant density. In the shoot, root, and fruit, the dry matter assimilation was higher in the HT than the other cultivars. Partitioning of dry matter in the individual cultivars showed no variation with plant density.

\subsection{Generative Components and Total Soluble Solids}

The cultivars showed a variation in terms of days to fifty percent flowering. The HT flowered 5 - 6 days earlier than the other cultivars (Table 3). Plant density did not affect the number of days to flowering. The HT plants grown in both high and low densities flowered earlier than the other treatments.

Fruit set percent was not markedly affected by plant density, cultivar, or their interactions (Table 3).

Table 2. Dry matter production and partitioning of tomato as influenced by plant density at 12 WAT.

\begin{tabular}{ccccc}
\hline Cultivar (C) & TPDM $\left(\mathrm{g} \mathrm{plant}^{-1}\right)$ & SDM $(\mathrm{g})$ & RDM $(\mathrm{g})$ & FDM $(\mathrm{g})$ \\
\hline HT & $186.7 \mathrm{a}$ & $78.2 \mathrm{a}$ & $19.7 \mathrm{a}$ & $88.8 \mathrm{a}$ \\
Lebombo & $106.5 \mathrm{~b}$ & $50.3 \mathrm{~b}$ & $16.4 \mathrm{~b}$ & $42.7 \mathrm{c}$ \\
Jaguar & $110.4 \mathrm{~b}$ & $32.8 \mathrm{c}$ & $17.4 \mathrm{~b}$ & $57.4 \mathrm{~b}$ \\
HSD $_{(0.05)}$ & 9.9 & 5.7 & 2.4 & 7.7 \\
& & Plant density $(\mathrm{PD})$ & & \\
High & $134.1 \mathrm{a}$ & $53.7 \mathrm{a}$ & $18.1 \mathrm{a}$ & $62.3 \mathrm{a}$ \\
Low & $134.9 \mathrm{a}$ & $53.8 \mathrm{a}$ & $17.5 \mathrm{a}$ & $63.6 \mathrm{a}$ \\
HSD $_{(0.05)}$ & 8.1 & 4.7 & 1.9 & 6.3 \\
& & & & \\
HT $\times$ high & $186.2 \mathrm{a}$ & $79.2 \mathrm{a}$ & $19.6 \mathrm{ab}$ & $87.4 \mathrm{a}$ \\
HT $\times$ low & $187.1 \mathrm{a}$ & $77.1 \mathrm{a}$ & $19.9 \mathrm{a}$ & $90.1 \mathrm{a}$ \\
Lebombo $\times$ high & $111.6 \mathrm{~b}$ & $50.2 \mathrm{~b}$ & $18.7 \mathrm{ab}$ & $42.7 \mathrm{c}$ \\
Lebombo $\times$ low & $109.3 \mathrm{~b}$ & $50.5 \mathrm{~b}$ & $16.0 \mathrm{~b}$ & $42.7 \mathrm{c}$ \\
Jaguar $\times$ high & $104.5 \mathrm{~b}$ & $31.8 \mathrm{c}$ & $16.0 \mathrm{~b}$ & $56.7 \mathrm{~b}$ \\
Jaguar $\times$ low & $108.4 \mathrm{~b}$ & $33.8 \mathrm{c}$ & $16.7 \mathrm{ab}$ & $57.9 \mathrm{~b}$ \\
HSD $_{(0.05)}$ & 14 & 8.1 & 3.4 & 10.9 \\
\hline
\end{tabular}

$\mathrm{HT}=$ Nkansah heat-tolerant tomato; TPDM = total plant dry mass; SDM = shoot dry mass; RDM = root dry mass; FDM = dry mass allocated to fruit; Figures with the same letter in the same column are not significantly different according to Tukey's HSD at $\mathrm{p}<0.05$. 
Table 3. Generative components and total soluble solids of tomato as influenced by plant density.

\begin{tabular}{|c|c|c|c|c|c|c|}
\hline Cultivar (C) & $\begin{array}{c}\text { Df } \\
\text { (days) }\end{array}$ & $\begin{array}{l}\text { FS } \\
(\%)\end{array}$ & $\mathrm{FNa}$ & $\begin{array}{l}\text { BER } \\
(\%)\end{array}$ & $\begin{array}{c}\text { Yield } \\
\left(\mathrm{kg} \cdot \mathrm{m}^{-2}\right)\end{array}$ & $\begin{array}{c}\text { TSS } \\
\text { (\% Brix) }\end{array}$ \\
\hline HT & $30 \mathrm{~b}$ & $99.5 \mathrm{a}$ & $150.7 \mathrm{a}$ & $0.0 \mathrm{~b}$ & $2.7 \mathrm{a}$ & $6.4 \mathrm{a}$ \\
\hline Lebombo & $35.8 \mathrm{a}$ & $98.3 \mathrm{a}$ & $40.4 \mathrm{~b}$ & $0.0 \mathrm{~b}$ & $1.4 \mathrm{c}$ & $6.7 \mathrm{a}$ \\
\hline Jaguar & $36 a$ & $99.6 \mathrm{a}$ & $19.6 \mathrm{c}$ & $51.73 \mathrm{a}$ & $2.3 \mathrm{~b}$ & $6.7 \mathrm{a}$ \\
\hline $\operatorname{HSD}_{(0.05)}$ & 0.6 & 1.3 & 3.8 & 7.1 & 0.2 & 0.4 \\
\hline \multicolumn{7}{|c|}{ Plant density (PD) } \\
\hline High & $33.9 \mathrm{a}$ & $99.4 \mathrm{a}$ & $82.3 \mathrm{a}$ & $17.2 \mathrm{a}$ & $2.5 \mathrm{a}$ & $6.7 \mathrm{a}$ \\
\hline Low & $33.9 \mathrm{a}$ & $98.9 \mathrm{a}$ & $58.1 \mathrm{~b}$ & $17.3 \mathrm{a}$ & $1.8 \mathrm{~b}$ & $6.5 \mathrm{a}$ \\
\hline $\operatorname{HSD}_{(0.05)}$ & 0.5 & 1.0 & 3.1 & 5.8 & 0.1 & 0.3 \\
\hline \multicolumn{7}{|c|}{$\mathrm{C} \times \mathrm{PD}$} \\
\hline $\mathrm{HT} \times$ high & $30 \mathrm{~b}$ & $99.6 \mathrm{a}$ & $179.1 \mathrm{a}$ & $0.0 \mathrm{~b}$ & $3.2 \mathrm{a}$ & $6.4 \mathrm{a}$ \\
\hline $\mathrm{HT} \times$ low & $30 \mathrm{~b}$ & $99.3 \mathrm{a}$ & $122.3 \mathrm{~b}$ & $0.0 \mathrm{~b}$ & $2.3 \mathrm{~b}$ & $6.4 \mathrm{a}$ \\
\hline Lebombo $\times$ high & $35.8 \mathrm{a}$ & $98.4 \mathrm{a}$ & $44.1 \mathrm{c}$ & $0.0 \mathrm{~b}$ & $1.5 \mathrm{~cd}$ & $6.9 \mathrm{a}$ \\
\hline Lebombo $\times$ low & $35.8 \mathrm{a}$ & $98.2 \mathrm{a}$ & $36.7 \mathrm{~d}$ & $0.0 \mathrm{~b}$ & $1.3 \mathrm{~d}$ & $6.4 \mathrm{a}$ \\
\hline Jaguar $\times$ high & $36 a$ & $100 \mathrm{a}$ & $23.8 \mathrm{e}$ & $51.5 \mathrm{a}$ & $2.9 \mathrm{a}$ & $6.6 \mathrm{a}$ \\
\hline Jaguar $\times$ low & $36 a$ & $99.3 \mathrm{a}$ & $15.3 \mathrm{f}$ & $51.9 \mathrm{a}$ & $1.7 \mathrm{c}$ & $6.7 \mathrm{a}$ \\
\hline $\operatorname{HSD}_{(0.05)}$ & 0.9 & 1.8 & 5.4 & 10 & 0.31 & 0.6 \\
\hline
\end{tabular}

H.T. = Nkansah heat tolerant tomato; Df = days to fifty percent flowering; FS\% = percent fruit set; Fna = fruit number per unit area; BER = percent fruit affected by blossom end rot; TSS = total soluble solids; Figures with the same letter in the same column are not significantly different according to Tukey's HSD at $\mathrm{p}<$ 0.05 .

The HT and Lebombo plants showed no incidence of blossom end rot (Table 3). However, $51 \%$ of Jaguar's fruits were affected by blossom end rot. Plant density did not affect the incidence of blossom end rot. Under the low and high plant densities conditions, fruits of the Jaguar cultivar were highly affected by blossom end rot compared to the HT and Lebombo.

The HT plants produced more fruits per unit area than the other cultivars (Table 3). Plants that received a high-density planting produced 24 more fruits per unit area than in the low-density planting. The lowest number of fruits was observed in the Jaguar plants that received the low-density planting. HT cultivar grown at high density produced 55 more fruits than same cultivar grown at low density.

The highest marketable yield per unit area was recorded in the HT plants, while the lowest was observed in the Lebombo (Table 3). High-density planting produced $0.7 \mathrm{~kg}$ more yield than the plants cultivated at a low density. The highest yield per unit area was produced in the HT and Jaguar plants, which were cultivated in high density compared to the other treatments.

Total soluble solids of the fruits did not vary with plant density, cultivar, and the interaction between plant density and cultivar (Table 3). 


\section{Discussions}

\subsection{Plant Growth}

Plants cultivated at a high density grew taller than those in a low density. This result confirms the findings of Tuan and Mao [24] and Gupta Shukla [25] that high plant density increased plant height. The observation might be associated with some degree of etiolation. A more significant number of plants growing in a unit area might have strived for more sunlight, thereby inducing stem elongation. The Lebombo plants exhibited a longer internode length and therefore grew taller than the other cultivars.

The HT plants produced a more significant number of leaves than the other cultivars. The HT cultivar was a determinate type, with three stems from which many leaves were produced. Leaf number was not affected by plant density, which is confirmed in Mahmoud's findings [26].

A high-density planting reduced chlorophyll content by $9.6 \%$ because of the shade effect. Plant density did not affect chlorophyll content in the HT compared to the other cultivars. The individual leaves in the HT plants were relatively smaller in size. As a result, the effect of leaf shading might have been minimized compared to the other cultivars.

Larger leaf size was produced in the Lebombo plants. This accounted for the larger leaf area in the Lebombo plants than the other cultivars. During high summer temperature (tropical) conditions, dry matter production efficiency and partitioning in Lebombo leaves were higher than the other cultivars.

\subsection{Dry Mass Production and Partitioning}

There was higher dry weight with HT cultivar's shoot, root, and fruits than the other treatments. This accounted for the higher total plant dry matter produced in the HT compared to the other cultivars. The higher leaf number and stem in the HT plants might have induced higher sink strength than the Lebombo and Jaguar. Additionally, the larger fruit number produced in the HT might have increased its sink strength compared to the other cultivars. Production of more photosynthates might have been induced in the HT plants because of the higher sink strength.

The Lebombo cultivar showed a higher photosynthetic area with higher efficiency in dry matter production. However, more of the dry matter produced was allocated to the leaves. The sink strength in the Lebombo fruits might have been limited. Therefore, dry matter assimilation to other organs was reduced compared to the HT. There was a low photosynthetic area but high efficiency in dry matter production in the Jaguar plants. Dry matter allocation to fruit was higher than in the vegetative parts.

\subsection{Generative Components and Total Soluble Solids}

Anthesis in the HT cultivar occurred six days earlier than the other cultivars. This observation may be due to genetic differences among the three cultivars. 
Regardless of the high summer temperatures, the percent fruit set was very high among the three cultivars. This result disagrees with Li et al. [9] that high temperatures reduce fruit set. The response of tomato fruit set to high temperatures stress is dependent on the cultivar.

However, the Jaguar cultivar showed a higher susceptibility to blossom end rot (BER) in the summer period. Marketable fruit number in the Jaguar was reduced by $51 \%$ due to BER. This result is in line with Rosales et al. [10] that high temperatures induce BER, as the reproductive organs (fruits) are highly hampered [27]. However, this result showed that some cultivars are not affected under heat stress regarding susceptibility to BER. Gunawardena and De Silva [28] indicated that the yield of tomatoes would adversely be affected during high temperatures. The HT and the Lebombo showed no record of BER compared to the Jaguar. Most probably, the fruits of the HT and the Lebombo cultivars had a higher store of calcium at their blossom ends than the Jaguar. These two cultivars might have also developed a better water and nutrient use efficiency with higher membrane integrity [29] than the Jaguar. The high summer temperatures might have accelerated the expansion of fruit in response to the transport of assimilates. Transport of assimilates and calcium in the HT and the Lebombo might have been well-coordinated at the blossom end of their respective fruits than the Jaguar.

A high-density planting increased fruit number by $42 \%$ due to more plants present per unit area. This result contradicts the findings of Balemi [30] that fruit numbers increased with low plant density. It was argued that there was low competition for resources for plants grown at low density. The HT produced more fruits per unit area, with a reduced fruit size than Lebombo and Jaguar. On the other hand, the Jaguar recorded the lowest fruit number per unit area. The reduction in fruit number for the Jaguar plants was due to the high incidence of blossom end rot. Adams and Ho [31] have explained this that cultivars which produce large fruit size are more susceptible to blossom end rot.

The marketable yield of tomatoes per unit area increased by $43 \%$ when was cultivated at high density. This work's findings showed that plant density affects yield against Geremew et al. [18], who reported that plant density does not affect the yield of tomatoes. The highest yield per unit area was recorded in the HT cultivar. This is because a higher total plant dry matter was produced with a higher dry matter allocation to the HT's reproductive sinks (fruits). The more significant fruit number in the HT might have induced an increased reproductive sink demand for assimilates than the other cultivars.

Similarly, the Jaguar cultivar grown at a high plant density produced a high yield as the HT. With a high dry matter apportioned to fruit in the Jaguar, the reproductive sink demand might have increased hence a higher yield than the Lebombo. Cultivar planting at a high density increased the yield per unit area of tomato by $15 \%$ - 70\%. This agrees with Ara et al. [14] and Akintoye et al. [19] that an increase in plant density increases the yield of tomato per unit area. In this study, the nutrient film hydroponic system might have induced a high 
osmotic gradient around the root zone, thus increasing the total soluble solids than that reported by Nkansah et al. [32] in Ghana.

\section{Conclusion}

Under summer temperature (tropical) conditions, the heat-tolerant tomato cultivar was best suited for cultivation compared to the other cultivars. The Lebombo showed a high degree of heat tolerance and resistance to the incidence of blossom end rot (BER) but, the fruit yield was low. Yield in the Jaguar cultivar was relatively as high as the HT. Notwithstanding it is uneconomical to cultivate the former during extreme high-temperature conditions because there could be a yield loss of $51 \%$ due to BER. The nutrient film technique hydroponic system adopted in this study may be affordable since a small quantity of substrate is required with efficient use of water and nutrients. Tomato cultivation could therefore be practiced at least three times per year. A high-density planting of the HT could produce a fruit yield of $9.6 \mathrm{~kg} \mathrm{~m}^{-2}$ in a year. This study shows that highdensity cultivation of the HT cultivar in NFT has the potential to increase Ghana's current tomato yield by 4.8 times. Under high tropical temperature conditions, further studies could be conducted using a drip hydroponic system with a slight increase in the substrate volume to assess the performance of the HT.

\section{Conflicts of Interest}

The authors declare no conflicts of interest regarding the publication of this paper.

\section{References}

[1] Sawicka, K., Rowe, E.C., Evans, C.D., Monteith, D.T., Vanguelova, E.I., Wade, A.J. and Clark, J.M. (2017) Modeling Impacts of Atmospheric Deposition and Temperature on Long-Term DOC Trends. Science of the Total Environment, 578, 323-336. https://doi.org/10.1016/j.scitotenv.2016.10.164

[2] Wang, H.J., Rutishauser, T., Tao, Z.X., Zhong, S.Y., Ge, Q.S. and Dai, J.H. (2017) Impacts of Global Warming on The Phenology of Spring Leaf Unfolding Remain Stable In The Long Run. International Journal of Biometeorology, 61, 287-292. https://doi.org/10.1007/s00484-016-1210-3

[3] Souri, M.K. and Hatamian, M. (2019) Aminochelates in Plant Nutrition: A Review. Journal of Plant Nutrition, 42, 67-78. https://doi.org/10.1080/01904167.2018.1549671

[4] Johkan, M., Oda, M., Maruo, T. and Shinohara, Y. (2011) Crop Production and Global Warming. In: Casalegno, S., Ed., Global Warming Impacts-Case Studies on the Economy, Human Health, and Urban and Natural Environments, IntechOpen, Croatia, 139-152.

[5] De la Peña, R. and Hughes, J. (2007) Improving Vegetable Productivity in a Variable Changing Climate. International Crops Research Institute for the Semi-Arid Tropics, 4, 1-22.

[6] Abdelmageed, A.H.A. and Gruda, N. (2009) Influence of Grafting on Growth, Development, and Some Physiological Parameters of Tomatoes under Controlled Heat Stress Conditions. European Journal of Horticultural Science, 74, 16-20. 
[7] Booker, F., Muntifering, R., McGrath, M., Burkey, K., Decoteau, D., Fiscus, E., Manning, W., Sagar, K., Arthur, C. and Grantz, D. (2009) The Ozone Component of Global Change: Potential Effects on Agricultural and Horticultural Plant Yield, Product Quality and Interactions with Invasive Species. Journal of Integrative Plant Biology, 51, 337-351. https://doi.org/10.1111/j.1744-7909.2008.00805.x

[8] Guodaar, L. (2015) Effects of Climate Variability on Tomato Crop Production in the Offinso North District of Ashanti Region. A Requirement for the Award of a Doctoral Dissertation, Kwame Nkrumah University of Science and Technology, Kumasi.

[9] Li, Z., Palmer, W.M., Martin, A.P., Wang, R., Rainsford, F., Jin, Y. and Ruan, Y.L. (2012). High Invertase Activity in Tomato Reproductive Organs Correlates with Enhanced Sucrose Import Into, and Heat Tolerance of, Young Fruit. Journal of EXperimental Botany, 63, 1155-1166. https://doi.org/10.1093/jxb/err329

[10] Rosales, M.A., Cervilla, L.M., Sánchez-Rodríguez, E., Rubio-Wilhelmi, M.D.M., Blasco, B., Ríos, J.J. and Ruiz J.M. (2010) The Effect of Environmental Conditions on The Nutritional Quality of Cherry Tomato Fruits: Evaluation of Two Experimental Mediterranean Greenhouses. Journal of the Science of Food and Agriculture, 91, 152-162. https://doi.org/10.1002/jsfa.4166

[11] Kugblenu, Y., Danso, E.O., Ofori, K., Andersen, M., Abenney-Mickson, S., Sabi, E., Plauborg, F., Abekoe, M., Jørgensen, S.T. and Jensen, C.R. (2013) Heat Tolerance in Field-Grown Tomatoes (Lycopersicon esculentum Mill.) Under Semi-Arid Conditions of West Africa. ISHS Acta Horticulturae, 971, 99-106. https://doi.org/10.17660/ActaHortic.2013.971.9

[12] Abdalla, A.A. and Verkerk, K. (1968) Growth, Flowering, and Fruit Set of the Tomato at High Temperature. Netherlands Journal of Agricultural Science, 16, 71-76. https://doi.org/10.18174/njas.v16i1.17428

[13] Zhou, R., Yu, X.Q., Kjaer, K.H., Rosenqvist, E., Ottosen, C.O. and Wu Z. (2015) Screening and Validation of Tomato Genotypes under Heat Stress Using $F_{V} / F_{M}$ to Reveal the Physiological Mechanism of Heat Tolerance. Environmental and Experimental Botany, 118, 1-11. https://doi.org/10.1016/j.envexpbot.2015.05.006

[14] Ara, N., Bashar, M.K., Begum, S. and Kakon, S.S. (2007) Effect of Spacing and Stem Pruning on the Growth and Yield of Tomato. International Journal of Sustainable Crop Production, 2, 35-39.

[15] Heuvelink, E., Marcelis, L.F.M., Bakker, M.J. and Vanderploeg, A. (2009) The Use of Crop Models to Evaluate Physiological Traits In Genotypes Of Horticulture Crops. Horticultural Production Chains Group, Wageningen University, Netherlands.

[16] Menberu, K., Derbew, B., Ali, M. and Yehenew, G. (2012) Effect of Intra-Row Spacing and Variety on Fruit Yield and Quality of Fresh Market Tomato (Lycopersicon esculentum Mill.) under Jimma Condition, Ethiopia. Ethiopian Journal of Science and Technology, 3, 32-42.

[17] Law-Ogbomo, K.E. and Egharevba, R.K.A. (2009) Effects of Planting Density and NPK. Fertilizer Application on Yield and Yield Components of Tomato (Lycospersi con esculentum Mill) in Forest Location. World Journal of Agricultural Research, 5, 152-158.

[18] Geremew, A., Teshome, A., Kasaye, T. and Amanti, C. (2010). Effect of Inter-Row Spacing with Double Row Arrangement on Yield and Yield Component of Tomato (Lycopersicon esculuntum Mill.) at Adami Tulu Agricultural Research Center (Central Rift Valley of Oromia, Ethiopia). African Journal of Agricultural Research, 6, 2978-2981. 
[19] Akintoye, H.A., Kintomo, A.A. and Adekunle, A.A. (2009) Yield and Fruit Quality of Watermelon in Response to Plant Population. International Journal of Vegetable Science, 15, 369-380. https://doi.org/10.1080/19315260903012110

[20] Fink, M., Kläring, H.P. and George, E. (2009) Horticulture and Climate Change. In: Dirksmayer, W. and Sourell, H., Eds., Water in Horticulture, Vol. 328, Landbauforschung, Sdh, 1-9. (In German)

[21] Bita, C.E. and Gerats, T. (2013) Plant Tolerance to High Temperature in A Changing Environment: Scientific Fundamentals and Production of Heat Stress-Tolerant Crops. Frontiers in Plant Science, 4, Article No. 273. https://doi.org/10.3389/fpls.2013.00273

[22] Solh, M. and van Ginkel, M. (2014). Drought Preparedness and Drought Mitigation in The Developing World's Drylands. Weather and Climate Extremes, 3, 62-66. https://doi.org/10.1016/j.wace.2014.03.003

[23] Hori, H. (1966) Gravel Culture of Vegetable and Ornamental Crops. Agri Hort Yoken-do, Tokyo, 210 (In Japanese).

[24] Tuan, N.M. and Mao, N.T. (2015) Effect of Plant Density on Growth and Yield of Tomato (Solanum lycopersicum L.) at Thai Nguyen, Vietnam. International Journal of Plant and Soil Science, 7, 357-361. https://doi.org/10.9734/IJPSS/2015/18573

[25] Gupta, A. and Shukla, V. (1977) Response of Tomato to Plant Spacing, Nitrogen, Phosphorus, and Potassium Fertilizer. Indian Journal of Horticulture, 34, 270-276.

[26] Mahmoud, S.H.M. (2005) The Effect of Cultivars, Seedbed Preparation, and Plant Density on The Growth and Yield of Tomato (Lycopersicon esculentum). MSc. Thesis, University of Kordofan, Sudan.

[27] Zinn, K.E., Tunc-Ozdemir, M. and Harper, J.F. (2010) Temperature Stress and Plant Sexual Reproduction: Uncovering the Weakest Links. Journal of Experimental Botany, 61, 1959-1968. https://doi.org/10.1093/jxb/erq053

[28] Gunawardena, M.D.M. and De Silva, C.S. (2016) Effects of Global Warming Simulated Temperature and Water Stress on Fruit Quality of Tomato (Lycopersicum esculentum) Var. Rajitha. OUSL Journal, 11, 93-112. http://doi.org/10.4038/ouslj.v11i0.7345

[29] Momcilovic, I. and Ristic, Z. (2007) Expression of Chloroplast Protein Synthesis Elongation Factor, EF-Tu, in Two Lines of Maize with Contrasting Tolerance to Heat Stress during Early Stages of Plant Development. Journal of Plant Physiology, 164, 90-99. https://doi.org/10.1016/j.jplph.2006.01.010

[30] Balemi, T. (2008) Response of Tomato Cultivars Differing in Growth Habit to Nitrogen and Phosphorus Fertilizers and Spacing on Vertisol in Ethiopia. Acta Agriculturae Slovenica, 91, 103-119. https://doi.org/10.2478/v10014-008-0011-8

[31] Adams, P. and Ho, L.C. (1992) The Susceptibility of Modern Tomato Cultivars to Blossom End Rot in Relation To Salinity. Journal of Horticultural Science, 67, 827-839. https://doi.org/10.1080/00221589.1992.11516315

[32] Nkansah, G.O., Owusu, E.O. and Denies, E.A. (2003) Effect of Mulch Types on Growth, Yield, and Fruit Quality of Tomato (Lycopersicum esculentum Mill). Ghana Journal of Horticulture, 2, 55-74. 